\title{
Alkali-Aggregate Reaction: Definition, Influence and Control
}

\author{
Juliana Maria McCartney da Fonseca ${ }^{1, ~ *, ~ V a n e s s a ~ K a r l a ~ B a r b o s a ~ d e ~ S o u z a ~}{ }^{1}$, \\ Deborah Grasielly Cipriano da Silva ${ }^{1}$, Dione Luiza da Silva ${ }^{1}$, Eliana Cristina Barreto Monteiro ${ }^{1,2}$ \\ ${ }^{1}$ Department of Civil Engineering, University of Pernambuco, Recife, Brazil \\ ${ }^{2}$ Department of Civil Engineering, Catholic University of Pernambuco, Recife, Brazil
}

Email address:

mccartney.juliana@gmail.com (J. M. M. da Fonseca), vanessa.kbs@hotmail.com (V. K. B. de Souza), deborahgrasielly@yahoo.com.br (D. G. C. da Silva), dione_luiza@hotmail.com (D. L. da Silva), eliana@poli.br (E. C. B. Monteiro)

${ }^{*}$ Corresponding author

\section{To cite this article:}

Juliana Maria McCartney da Fonseca, Vanessa Karla Barbosa de Souza, Deborah Grasielly Cipriano da Silva, Dione Luiza da Silva, Eliana Cristina Barreto Monteiro. Alkali-Aggregate Reaction: Definition, Influence and Control. Engineering and Applied Sciences.

Vol. 3, No. 1, 2018, pp. 12-20. doi: 10.11648/j.eas.20180301.13

Received: December 29, 2017; Accepted: January 11, 2018; Published: March 14, 2018

\begin{abstract}
The alkali-aggregate reaction is a pathological manifestation due from chemical processes of interaction of reactive minerals that are present in some aggregates, and alkali hydroxides from Portland cement, water kneading and external agents dissolved in the solution present in the pores of concrete. It is a reaction that occurs slowly, but may cause irreparable damage, for example with cracks that impair the mechanical strength and durability of the affected structure. The main objective of this work is to expand the existing knowledge about the evolution of this pathological manifestation in order to contribute to eradicate this problem in the construction works. The methodology used in the article includes a literature review that addresses a history of occurrence of alkali-aggregate reaction in Brazil and around the world, its definition, the types of reaction, the factors that influence it, control methods and some cases in Metropolitan region of Recife that had this pathological manifestation during the construction process and during its lifetime. The article here presented is intended to contribute to spreading a deeper understanding of this pathological manifestation as well, pointing out mitigating actions of its occurrence, it is a relevant tool for the technical means, the expected result with this production is to increase the knowledge of the theme proposed, as the increasing number of occurrence of this pathological manifestation in concrete structures.
\end{abstract}

Keywords: Alkali-Aggregate Reaction, Pathological Manifestation, Control

\section{Introduction}

The first reports of the alkali-aggregate reaction (AAR) were carried out in 1940 in California, studied by the first by Stanton, an English researcher. He identified the AAR as a highly damaging reaction that occurred between the silica of the aggregate, the alkalis of the cement and the constituents of the concrete. According to the author, the reaction manifests itself through white efflorescences, causing expansion and cracking in concrete, he concluded these characteristics through observations in affected structures in California at the time of the discovery [1].

This discovery caused the interest of some researchers in the area and encouraged the initiation of various researches related to the problem, due to the irreversible damage that this pathological manifestation can cause in the structures affected. These studies contributed to clarify the appearance of this pathological manifestation, considering its chemical process, the identification of the reactive minerals and the damages caused by it [2].

One of the first theories formulated to explain the expansion mechanism of the AAR was developed by Hansen, 1944, and was termed osmotic pressure. Hypothetically, the reaction products were confined within a semipermeable membrane of the cement paste and under hydraulic pressures, causing the expansion in the structure of concrete [3]. 
Between 1950 and 1960 the study of the AAR lost its strength and the researches on the subject has been taken up in The 70's, from the appearance of these anomalies in several countries.

Several affected structures were diagnosed in various parts of the world since the discovery of the AAR phenomenon, among them: the Val de La Mare dam (United Kingdom), the Sandouping dam (China), the La Tuque dam (Canada), the Kouga dam (South Africa), the Chambon dam (France) and etc. The Table 1 shows the countries that were more affected by AAR [4].

Table 1. Case numbers of countries affected by AAR [5].

\begin{tabular}{ll}
\hline Country & Number of Cases \\
\hline France & 5 \\
Norway & 7 \\
South Africa & 10 \\
Brazil & 20 \\
USA & 29 \\
Canada & 41 \\
\hline
\end{tabular}

In view of the above, the present work consists in the approach to a history of the occurrence of the alkaliaggregate reaction in Brazil, and in the world, its definition, the types of reaction, the factors that influence it, the methods of control and some cases in the Metropolitan Region of Recife that presented this pathological manifestation during the construction process and during its useful life, aiming to contribute to the eradication of this pathological manifestation in the construction works.

\section{Alkali-Aggregate Reaction in Brazil}

Table 2. Reactive potential of Brazilian commercial aggregates. [29].

\begin{tabular}{llll}
\hline & & \multicolumn{2}{l}{ Potencialidade Reativa (\%) } \\
\hline & Total & Potencialmente & Potencialmente \\
\hline State & Samples & Inócua & Reativa \\
\hline Brazil & 1994 & 64 & 36 \\
SP & 532 & 66 & 34 \\
PE & 228 & 71 & 29 \\
PI & 45 & 44 & 56 \\
BA & 70 & 59 & 41 \\
RJ & 119 & 100 & 0 \\
RS & 41 & 27 & 73 \\
MG & 58 & 65 & 35 \\
\hline
\end{tabular}

Since the $1960 \mathrm{~s}$, Brazil has started the first works on AAR, starting with the construction of the Jupiá dam, whose gravel from Paraná River presented the chalcedony reactive phase. There are more than 20 confirmed cases of dams affected by this reaction in Brazil, among them are the Apolônio Sales dam, located on the between Bahia and Alagoas; the Billings / Pedras dams, located in the state of São Paulo; the Furnas dams, in Minas Gerais and the Joanes dam in the state of Bahia. The disclosure of the first dam case occurred in 1985, in the Apolonio Sales de Oliveira Hydroelectric Plant (Moxotó) [5]. In 1988, the presence of the reaction was confirmed in the dam of Joanes II (BA). In the 1990s, the occurrence of AAR was observed in several dams and, in all the cases investigated, the reaction was alkali-silicate type [6].

According to a survey of the reactivity of commercial aggregates made by the Brazilian Portland Cement Association ABCP (2016), it can be seen that at least $40 \%$ of the aggregates used in Brazil are potentially reactive.

\section{Alkali-Aggregate Reaction in Pernambuco}

The first AAR reports in Pernambuco happened in the city of Recife, where it was realized an investigation work on the Paulo Guerra Bridge, which links the district of Pina to the center of Recife and aggressive deterioration was detected in foundation blocks, by the alkali-aggregate reaction [7]. Approximately 20 cases of foundation elements with alkaliaggregate reaction were discovered in the metropolitan region of Recife between the ages of 3 and 30 years. The reactivity potential of small and large aggregates from the Metropolitan Region of Recife were evaluated by the same authors who concluded that the majority of the analyzed aggregates had potentially reactive phases which effectively contributed to the occurrence of the reaction, especially in the foundation blocks [7].

\section{Alkali-Aggregate Reaction (AAR)}

\subsection{Definition}

The alkali-aggregate reaction (AAR) is a pathological manifestation that occurs through a chemical reaction that happens internally in a concrete structure between the alkali hydroxides (generally based on sodium and potassium, from cement, kneading water, chemical additives, among others) and some types of minerals reactive present in the aggregates (in general the presence of amorphous silica, potentially reactive, such as volcanic glass, chalcedony and some carbonate rocks, for example). As a result of the reaction, are formed products which, in the presence of moisture, are able to expand, generating internal stresses in the concrete structure resulting in fissures, displacements and may lead to deterioration of structures.

The AAR is a slow reaction, occurring in concrete structures, formed by the reaction between some minerals that make up the aggregates and alkaline hydroxides from the cement. This type of pathological manifestation compromises the mechanical characteristics of the concrete, and there may be loss of tensile and compressive strength [8].

The AAR affects several typologies of concrete works, however, it will only develop in the presence of moisture [9]. It is emphasized that the condition of minimum ideal moisture inside of the concrete for the reaction to be generated is given in percentages above $85 \%$ at $20^{\circ} \mathrm{C}$ [10]. The time for the phenomenon to be consummated is quite variable, since the reaction speed is related to several factors, such as the available soluble alkali contents, the nature, size and quantity of reactive aggregates, ambient temperature, 
humidity and physical restrictions to the reaction. Considering the reactive chemical principles in which the speed of a reaction is greater the smaller is the particle size, through a larger contact surface; it would be expected that the reduction of the particle size of the aggregates would cause an increase of expansion through AAR. However, experiments did not prove this hypothesis, since the largest expansions of AAR in concrete occurred in aggregates whose sizes were intermediate [11].

Despite the temporal variability of AAR, sudden collapses due to these reactions are significantly rare, since these manifestations usually present symptoms that are commonly perceptible and can be corrected throughout the useful life of the structure or until one of the reagents is consumed and / or the moisture is reduced [12].

Although known since the mid-1940s in California, its complete mechanisms are still not fully known by the scientific community.

\subsection{Types of Alkali-Aggregate Reaction}

The alkali-aggregate reaction is a deleterious chemical reaction that occurs between the alkaline ions present in the hydrated cement paste and the minerals present in some types of reactive aggregates. It can be classified into three types of reaction as a function of the reactive mineral present in the aggregate: alkali-carbonate reaction (ACR), alkali silicate reaction (ASSR) and alkali-silica reaction (ASR), this being the most frequent type of reaction in Brazil [13].

\subsubsection{Alkali-Silica Reaction (ASR)}

This reaction occurs when the reactive silicas present in the aggregates react with the hydroxyl ions present in the concrete structure. The silica reacts with the sodium and potassium alkali forming an unstable silica-alkaline gel, which absorbs water and expands, occupying a larger volume than the materials that preceded the reaction [14]. The ASR is the fastest-growing reaction, where the expansive gel is formed from the reactive silica of the aggregates and the alkalis in the presence of calcium hydroxide, a component present in the cement paste. In a embracing way, there are two forms of silica present in the aggregates, they are: crystalline and amorphous silica [15].

The AAR occurs in two forms, one when the attack of the hydroxyl ions occurs on the well crystallized surface of the silica, as in Figure 1, and the other when the silica is amorphous. The process of attack of hydroxyl ions on the crystalline silica is fairly long, with a few silica ions becoming fluid. Whereas in the amorphous silica the generalized penetration of hydroxyl and alkaline ions is conceived, breaking the bonds of the siloxane group ( $\mathrm{Si}-\mathrm{O}$ Si) [14].

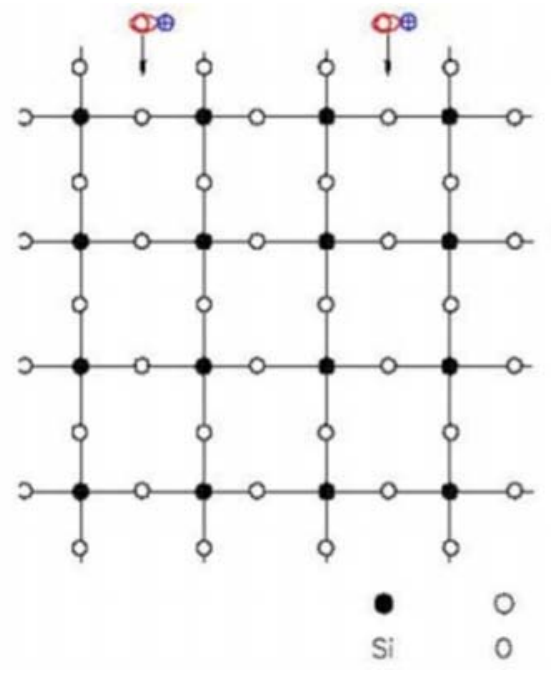

a) Crystalline silica

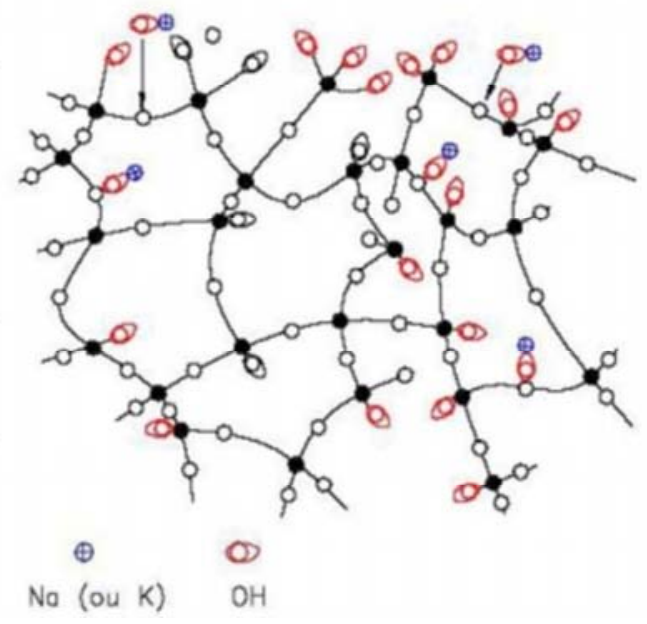

b) Amorphous silica

Figure 1. Hydroxyl attack on silica [14].

\subsubsection{Alkali-Silicate Reaction (ASSR)}

It is the type of AAR most found in dams built in Brazil [16]. It have been commonly used in the construction of these structures aggregates originating from quatzites, granites and gneisses, minerals, believing in the stability of these aggregates in the use of concrete, since quartz was one of the most stable materials found in nature. Later, it was found that this quartz had a structure that differed from stable quartz, known as "deformed quartz", in which it showed significant signs of reactivity [17].
The ASSR is a specific type of alkali-silica reaction, which occurs more slowly than ASR (since the reactive minerals are widespread in the crystalline lattice of the aggregate), where the most common reactive silicates are quartz tensioned by tectonic processes and the minerals found in the classes of phyllosilicates found in slates, phyllites, schists, gneisses, granulites, quartzolites, among others [15]. The similarity of ASSR to ASR makes it difficult to diagnose the type of these two pathological manifestations, since it is possible to verify the product of the alkali-silica reaction inside the concrete [18]. 


\subsubsection{Alkali-Carbonate Reaction (ACR)}

It consists of the less common reaction, occurring when certain dolomitic limestones are used as aggregate in concrete, reacting with the alkalis present in the cement paste, a reaction also called desdolomitization, modifying the limestone structure, resulting in the expansion of the products of the reaction, which, unlike ASR and ASSR, do not form expansive gel, but crystallized compounds. The alkaline hydroxide regenerates, weakening the transition zone between the aggregates and the cement paste, cracking it due to the loss of adhesion of the materials [16].

In Brazil there are no recorded cases of alkali carbonate reaction occurrence [19]. Many alkali-carbonate reactions have been reported, but not all have been expansive [14]. These reactions are, therefore, classified according to the products resulting from their respective reactions, to quote:

a) Carbonited with calcitic aggregates, characterized by the edge manifestation of dark reaction that develop around the particles of the aggregates;

b) Dolomite aggregates, characterized by the different reactions around the aggregate;

c) Fine dolomite aggregates with calcites and interstitial clays, promoting desdolomitation, the only one capable of producing expansive compounds.

\section{Methods of Control and Prevention of Alkali-Aggregate Reactions}

Once the presence of AAR has been identified, its interruption as well as the recovery of the affected structure occurs costly and complicated. In view of the occurrence of this pathological manifestation and in view of the great difficulty of stagnating its effects, it must be assumed that all aggregates are reactive with the cement alkalis until proven otherwise [20].

In order to control the AAR, it is necessary to monitor the structure in process of AAR with the objective of:

a) Check if the concrete is still expanding;

b) Characterize the rate of expansion with time, defining whether it is evolving in a decreasing, constant or growing mode;

c) To enable the calibration of the mathematical models of structure behavior analysis;

d) Check the efficiency of repair works, if performed;

e) Monitor the increase in structure deformability, internal cracking and distortions on the limits of rupture and use of the structure.

Among the instruments most used for the monitoring of AAR are the thermometers (temperature measurement), piezometers (pressure measurement), rod extensometers (displacement measurement, strain and expansion rate), tape extensometers (relative displacement measurement ), topographic framework (measuring vertical and horizontal displacements), "Strain Gage" (measurement of deformation in concrete and reinforcement), triortogonal meter (measurement of opening or closing displacements and differential displacements), humidity meter (measurement of the internal humidity of the concrete) and automation sensors (automation of the readings) [20].

For the prevention and neutralization of the AAR, it is necessary to adopt measures such as the choice of nonreactive aggregates (avoiding also aggregates with very large specific surface, since they increase the reaction), the use of mineral additions (when it is not possible avoiding reactive aggregates, part of the cement can be replaced by mineral additions) and the use of chemical additions (with similar principles of mineral additions, but its content should be considered, since some additives may be a source of alkali) [21].

\section{Occurrences of Alkali-Aggregate Reactions in the Metropolitan Region of Recife/PE}

At first, when studied, the alkali-aggregate reaction was frequently associated with dams and large-scale works, however, these reactions can be found in several types of concrete structures, and can be verified in the Metropolitan Region of Recife where several studies attest the presence of pathological manifestations compatible with AAR in buildings [22].

In Recife-PE, where the first cases of AAR were discovered in building foundations, concrete and concrete constructors were researched and shown to be more and more concerned with using materials that mitigate the appearance of this type of pathological manifestation. It was found that $100 \%$ of the interviewees use metacaulim and active silica in the concrete and monitor the deposits with tests to verify the aggregate reactivity [23].

Although not yet studied by the technical environment, there are a large number of occurrences of AAR in the Metropolitan Region of Recife, which is very worrying, since the recovery of the affected structures is quite complex and has a high cost, making it necessary to improve adequate solutions for the correction of this pathological manifestation [24].

\subsection{Paulo Guerra Bridge (Recife/PE)}

\subsubsection{Bridge Description}

Inaugurated in 1979, the Paulo Guerra Bridge stands on the Pina River basin, in a region close to the sea, therefore subject to the variation of the tides. It connects the districts of Cabanga and Pina and gives access to the South Zone of the city, where is the most populous district of Recife - Boa Viagem.

According to the technical report of EMLURB - Urban Maintenance and Cleaning Company, belonging to the City Hall of Recife, in 1999 the Paulo Guerra Bridge has a total length of $453 \mathrm{~m}$, is made of prestressed concrete, has a $15 \mathrm{~m}$ wide rolling range, rides sides of $2 \mathrm{~m}$ and guard wheels and $50 \mathrm{~cm}$ thick.

The superstructure is formed by two unicellular coffins 
joined by the upper slab. The lower slab has variable height and the upper one, constant. It has seven continuous spans of $47 \mathrm{~m}$, with two extreme swings of $18.50 \mathrm{~m}$, at its ends, Gerber teeth, isostatic spans of $10.10 \mathrm{~m}$ in length.

\subsubsection{Damage from Alkali-Aggregate Reaction}

According to a case study carried out, all the support blocks of the main beams of the bridge presented pathologies worthy of attention, mainly cracks. The fissure frame varied from block to block, usually in "spider web" or "map" format, some with large openings.

The fissures were predominantly in the blocks themselves, but they could also be seen in the calyxes and the pre-welded plates that cover the calyces and their bases (Figure 2). This framework of cracking in concrete pieces is characteristic of the occurrence of alkali-aggregate [25].

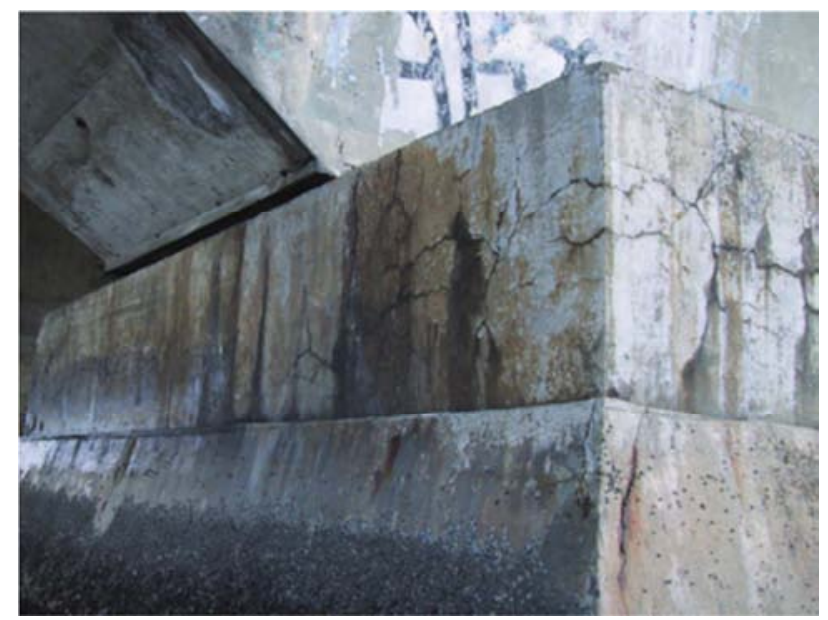

Figure 2. Signs of AAR in the central span support block of the Paulo Guerra Bridge [26].

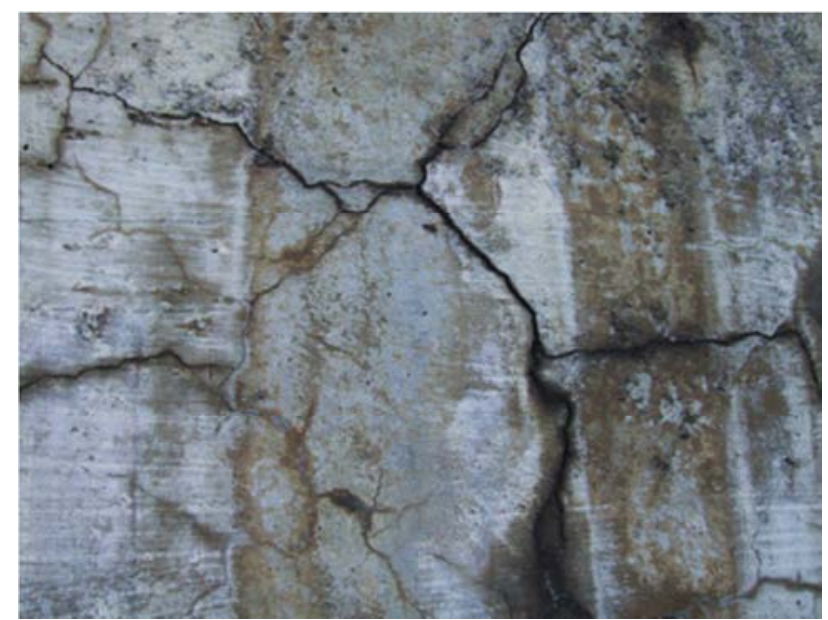

Figure 3. Crack in the shape of a map in the foundation block of the Paulo Guerra Bridge [26].

\subsubsection{Solution Adopted}

After performing the petrographic analysis tests to verify the durability of the concrete there were carried out analyzes using stereoscopic microscopy, optical and electronic scanning of the tests pertinent to the diagnosis of AAR. With the tests, the occurrence of AAR in the alkali-silicate type was confirmed and it was observed through macroscopic analysis, several reaction characteristics, such as white material filling pores and defining edges at the interface, aggregate-mortar, later identified in the scanning electron microscope as an expansive gel.

Due to the local conditions and the advanced deterioration, the solution adopted for the recovery of the bridge was a structural project that chose to take advantage of the existing blocks, recovering them and reinforcing them through an encapsulation in reinforced concrete. This seemed to be the best alternative. As it is not possible to keep the concrete away from the water, it is expected that the AAR will continue in the foundation block. The designed confinement needed to withstand the forces of reaction expansion. For this purpose, it was decided to use a confinement force capable of withstanding tensile stresses of the order of $4 \mathrm{MPa}$ (580 psi) [26].

\subsection{Commercial Building in Recife}

\subsubsection{Building Description}

The building studied has commercial purpose and it was built in the year of 1980 with an arrangement of 11 floors and with a constructed area of approximately $15,000 \mathrm{~m}^{2}$. The foundation of the building is composed of reinforced concrete blocks on franki-type piles whose structure is in reinforced concrete.

\subsubsection{Damage from Alkali-Aggregate Reaction}

It is written that after the rupture occurred in the Areia Branca Building and with the evidence of similar occurrences in the foundations of other buildings in the city of Recife, it was decided to inspect the foundations of the mentioned building. In the study, a very severe cracking picture was observed, both by the number of cracks and by the magnitude of its openings. Figures 3 and 4 present the pathological condition of the foundation blocks of the building [25].

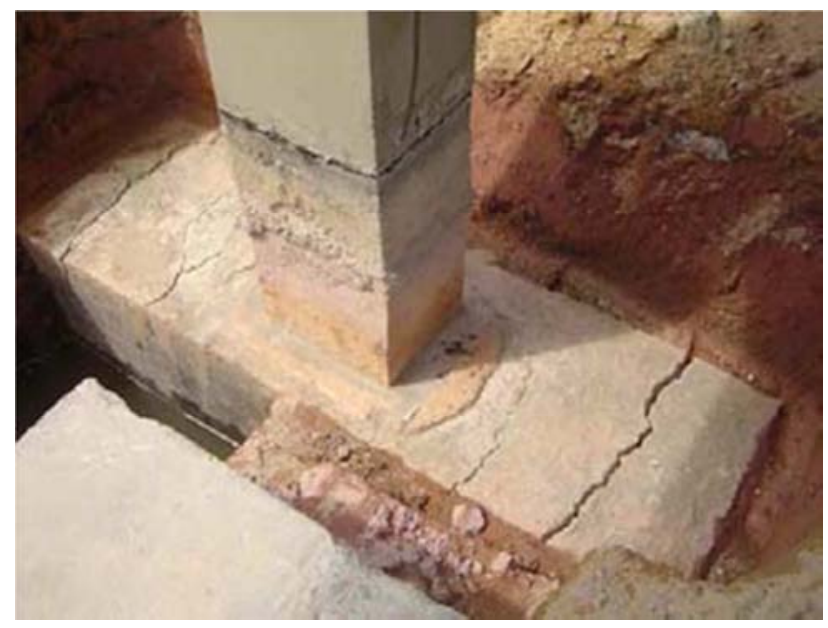

Figure 4. Fissure in block on two stakes, with dimensions 1 x 2,5m [25]. 


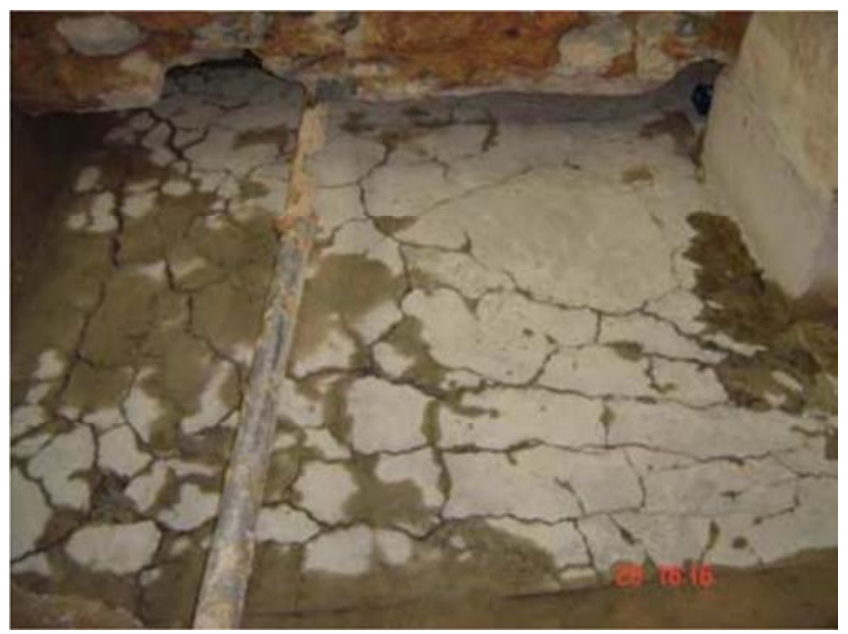

Figure 5. Block fissure with 18 stakes, with dimensions $8 \times 6 m$ [25].

In the analyzes it was observed that in some cases, besides the vertical cracks in the blocks on two stakes have exceeded the connecting rods, in two cases, at the bottom of the building, the AAR weakened the blocks to such an extent that there were redistribution of loads to other blocks.

\subsubsection{Solution Adopted}

The company responsible for the recovery was JLC Project Engineering Ltda., from Rio de Janeiro and with the table presented, a mechanism was necessary to recompose the section of the block, introducing compression stresses in the block, through pretension (being in the larger blocks made in two directions), using Dywidag bars. In addition, it was necessary to seal the block to prevent the subsoil water from reaching the block by capillarity, thus re-feeding the alkaliaggregate reaction process.

\subsection{Public Building in Recife}

\subsubsection{Building Description}

It is a building of public use in Recife, and it was built in 1993 with 13 floors. In 2005, at the age of 12, in a small reform of the adequacy of his architectural model, excavations were made close to one of the pillars of the public building where the existence of pathological manifestations was discovered.

\subsubsection{Damage from Alkali-Aggregate Reaction}

The foundation blocks presented a picture of cracks, with the largest blocks of the building (stakes 8 and 9), the blocks with more intense and variable cracks, while the secondary blocks (stake 1) were intact. Figures 5 and 6 show the cracks painted in color and the largest crack found in the work, respectively [25].

Considering the table presented and the analysis of the tests carried out, there is no doubt about the strong existence of AAR in the foundation blocks, being evidenced a high expansion in the blocks due to the favorable conditions to its development as the presence of reactive aggregate, alkalis and humidity.

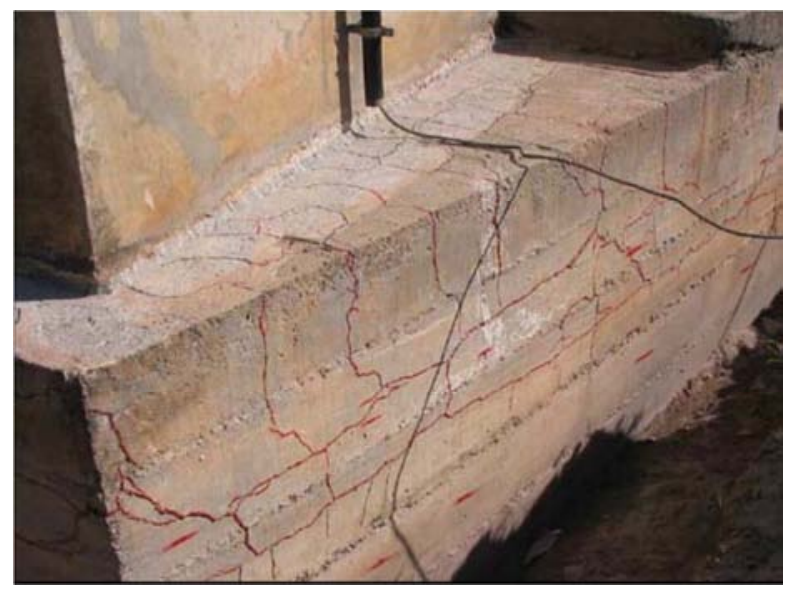

Figure 6. Upper and lateral block faces with cracks painted [25].

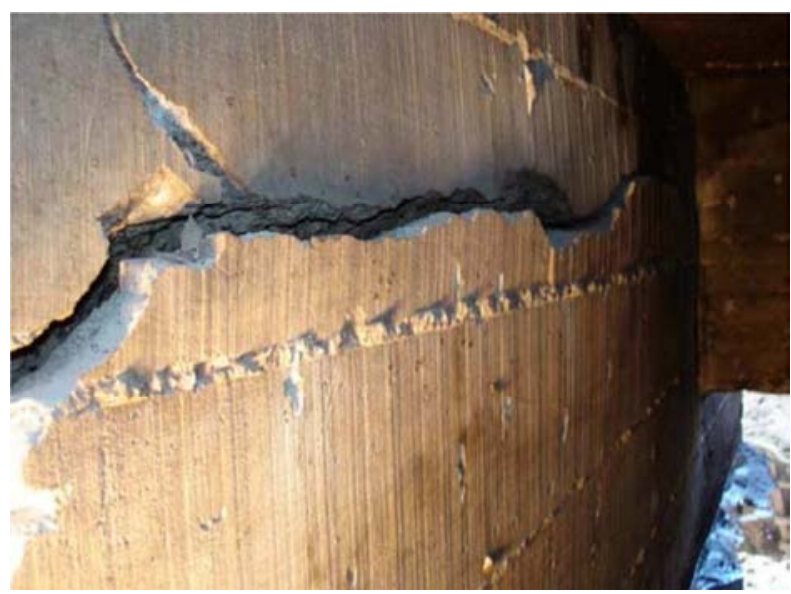

Figure 7. Horizontal crack with large opening and displacement [25].

\subsubsection{Solution Adopted}

With the confirmation of the occurrence of the AAR in the foundation blocks, the structural recovery actions were defined. The solution adopted was concentrated in two steps the closing of the cracks and the intensification of the reinforcement. The closure of fissures and cracks with appropriate material had the main objective of protecting the blocks against the possible entry of deleterious product and humidity, factors that aggravate the alkali-aggregate reaction. The recovery of the blocks aimed at reconstituting the rigidity of the same and intensificate the reinforcement that combats the tensile stresses and in order to promote the sealing of the same ones with waterproofing material, to inhibit the continuation of the AAR process [25].

\subsection{Residential Building in Recife}

\subsubsection{Building Description}

The building analyzed is of residential type, has 19 floors and a constructed area of approximately $13,000 \mathrm{~m}^{2}$. Built in 1980, the residential building features reinforced concrete structure, with fck $\geq 18 \mathrm{MPa}$ and foundation in blocks of reinforced concrete on stakes type Franki.

\subsubsection{Observed Damage}

From the history of this residential building it is known 
that in the year 1983, three years after its construction, the work had already presented fissures in some blocks, being reinforced the ones. However in 2008 it was found that some blocks which had not been reinforced in 1983, now presented many fissures in the lateral and upper faces, with similar aspect to those of several buildings in which the existence of AAR was already established in the metropolitan area of Recife. Figure 7 shows the cracks in the foundation block already filled with microcement [25].

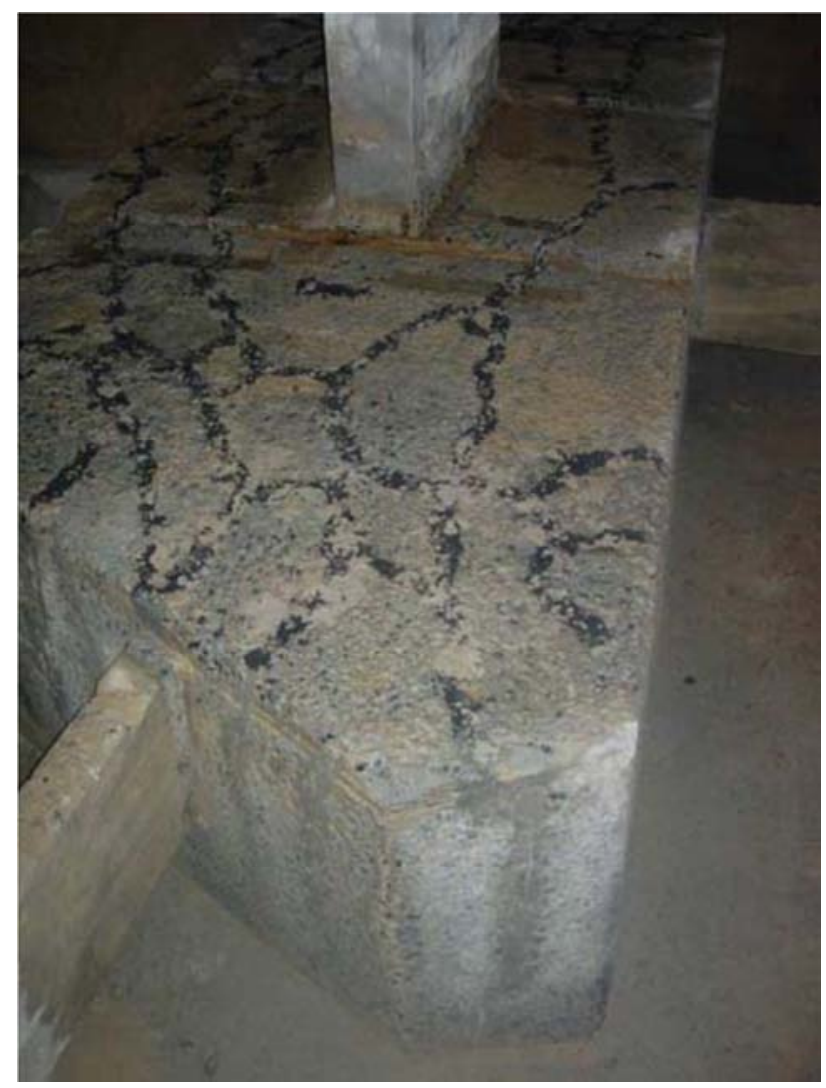

Figure 8. Foundation block with cracks already filled [25].

\subsubsection{Solution Adopted}

Confirming the existence of AAR in the blocks and considering the advanced age of the building - 30 years, it was suggested that most of the expansion of the reaction had already occurred. Thus, it was recommended to solve the problem the filling of the fissure with microcement and subsequent encapsulation of the block with concrete layer in the lateral and upper faces, being recommended concrete with fck $\geq 40 \mathrm{MPa}$ with metakaolin addition, in order to inhibit the incidence of AAR in the new concrete.

\subsection{Residential Building in Recife}

\subsubsection{Building Description}

The multi-family residential building located in the Metropolitan Region of Recife, Jaboatão dos Guararapes, located in the northeast of Brazil was built 12 years ago. It has its mesostructure in reinforced concrete, being supported under direct foundation (superficial), that is, it has low shoes that are supported in the ground, on a layer of $5 \mathrm{~cm}$ lean concrete. The structural concrete specified in the project presented 25Mpa [27].

\subsubsection{Observed Damage}

The construction of the building started in 1998 and ended in 2002. Fearful after the collapse of the Areia Branca building in 2004, the building's residents hired an inspection of the property in 2005, mainly due to the cracks found in the shoes. Although the appropriate tests for the diagnosis of the cracks had not been performed, the low shoes were recovered with the injection of rigid epoxy resin. In 2014, there was a new inspection to evaluate the state of the low shoes and it was verified that the ones inspected and recovered in the past have returned to many cracks and fissures (Figures 9 and 10). From this, the tests of resistance to compression of these shoes were made and, after studying the history of the foundation, the environmental factors and the characteristics of the building and in front of the realized tests, it was concluded that the foundation presented the picture of known pathological manifestation as an alkali-aggregate reaction [27].
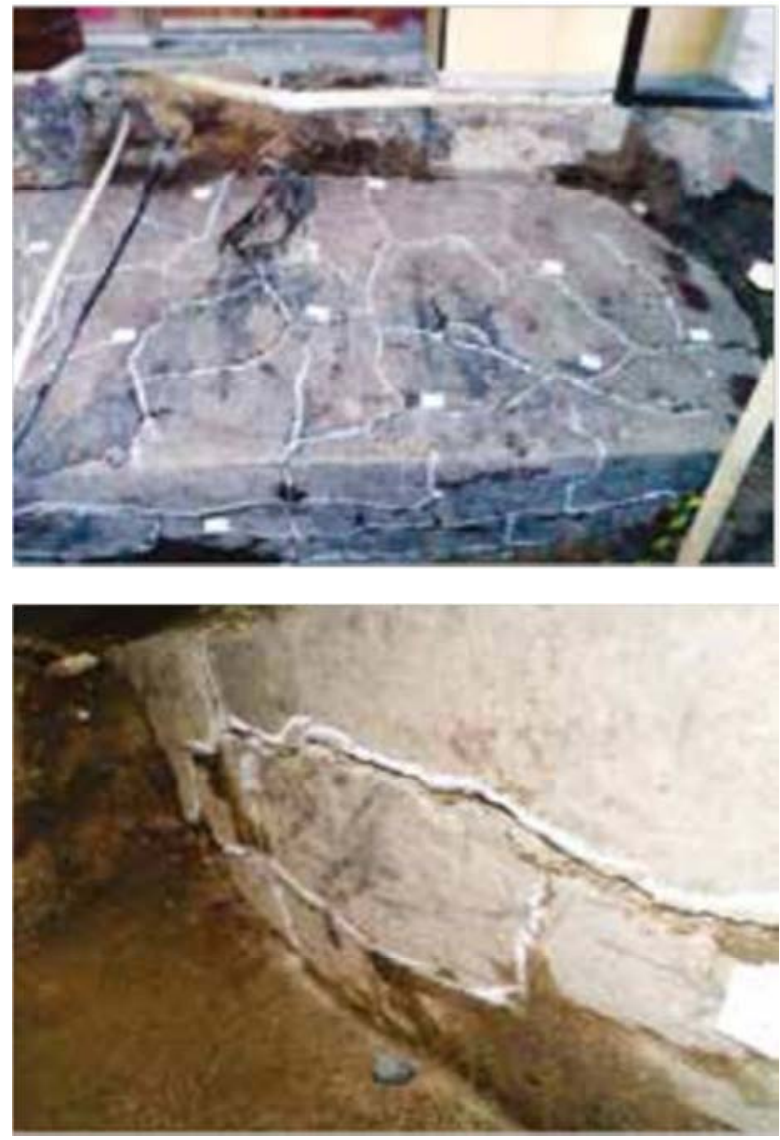

Figure 9. Low shoes with cracks in maps marked with chalk [27].

\subsubsection{Solution Adopted}

The excavation was carried out around the shoes that were buried. After the faces of the shoes were excavated, the cleaning procedure was carried out with the washing of the structure, using a high pressure jet equipment for better visualization of the areas affected by cracks and fissures, 
followed by the removal of specimens to verify in the laboratory if the fissure was caused by AAR. The next stage consisted in removing the epoxy from the previously received area, then performing the bore, blowing and cleaning procedures of the cracks and fissures, placing traps (a kind of plastic hose with a diameter of $10 \mathrm{~mm}$ ) that were spaced apart approximately $250 \mathrm{~mm}$ apart and penetrated 90 $\mathrm{mm}$ (Figure 11) for injection and a micro-slurry. For cracks greater than $10 \mathrm{~mm}$, it was preferable to use the grating. Already, for the surface clogging, which avoids the exit of the material inserted inside the structure, a mixture of epoxy and kaolin was used. Finally, it was chose the encapsulation for the structural reinforcement of the shoes, in order to restrict the expansion as much as possible, to have a good capacity to prevent the passage of water.

The recovery service was incomplete because, at the end of the shoe encapsulation, these were not waterproofed, which may facilitate the penetration of aggressive external agents and moisture. The method described in this work is the most widely used and known to the present moment for recovery of alkali-aggregate reaction, but it is not totally effective. The proof of this, is that some shoes that had already been recovered previously but, after a few years, returned to present the fissures [27].

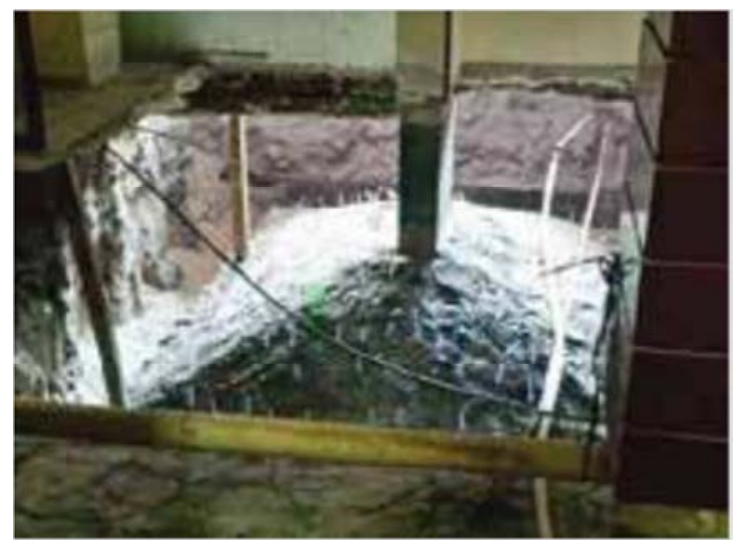

Figure 10. Low shoe bleeders [27].

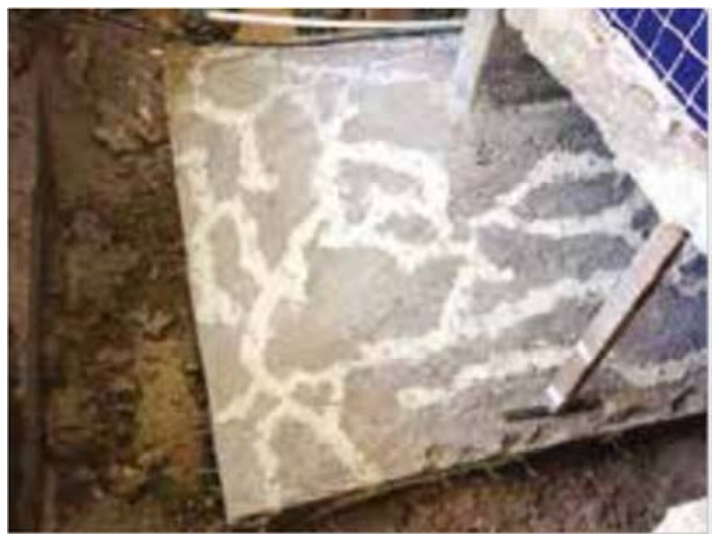

Figure 11. Cracks and fissures clogging [27].

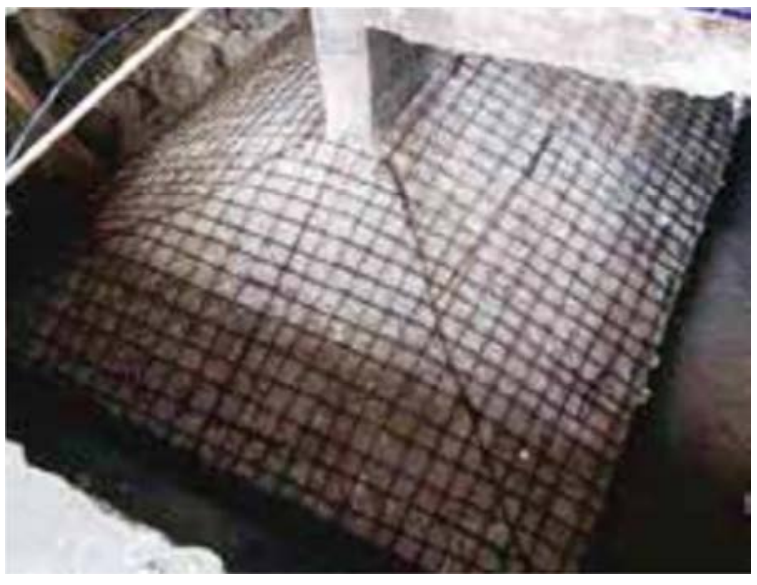

Figure 12. Steel mesh for shoe encapsulation [27].

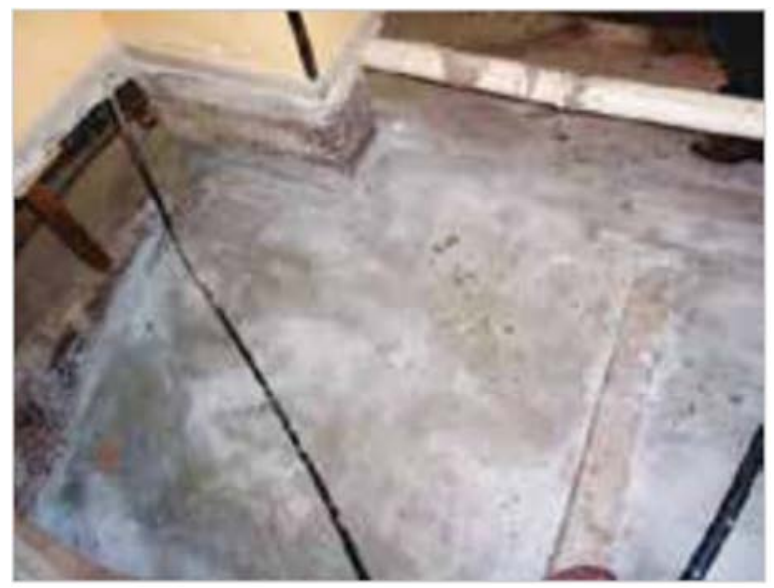

Figure 13. Concreted shoe [27].

\section{Conclusion}

The number of AAR occurrences in the Metropolitan Region of Recife is increasing, thereby it is necessary the improvement of adequate solutions to correct this pathological manifestation.

Although cases of sudden collapse of structures due to AAR are extremely rare, this pathological manifestation may trigger other types of chemical aggression in the affected structure that may compromise its performance, durability and safety.

It is necessary to seek solutions that prevent the appearance of this pathological manifestation in new structures because even if corrective solutions are not available, it can be avoided that it manifests itself with effective methods of prevention.

In order to avoid the propagation of reactions it is necessary to verify the reactive potential of the aggregates, taking the preventive measures in the appropriate time, so it is fundamental knowledge of the characteristics of the aggregates, their physical and chemical properties, in order to know the type of reaction that affected the structure to make a correct diagnosis. 


\section{References}

[1] STANTON, T. E. Expansion of concrete through reaction between cement and aggregate. In: Proceedings of American Society of Civil Engineers. v. 66, n. 10. Dec. 1940, p. 17811811.

[2] SANCHES, L. F. M. "Contribuição ao estudo dos métodos de ensaio na avaliação das reações Alcali-agregado em Concreto". Dissertação (Mestrado em Engenharia Civil). Universidade Estadual de São Paulo- USP. São Paulo, 2008.

[3] PAULON, V. A. "Reações álcali-agregado em concreto". São Paulo, Dissertação (Mestrado em Engenharia Civil) - PósGraduação em Construção Civil, Escola Politécnica da Universidade de São Paulo. 1981. 125p.

[4] SILVEIRA, A. L. et al., "Investigação da reação álcaliagregado em rochas carbonáticas". In: II Simpósio Sobre Reação Álcali-agregado em Estruturas de Concreto. 2006, Rio de Janeiro. Anais. São Paulo: IBRACON, 2006. 1 CD-ROM.

[5] KIHARA, Y. "Reação álcali-agregado: Mecanismo, Diagnose e Casos Brasileiros". In: Congresso Brasileiro de Cimento, 3., 1993. São Paulo. Anais. São Paulo: ABCP, 1993. v. 1, p. 319337.

[6] HASPARYK, N. P. "Investigação dos mecanismos da reação álcali- Agregado - efeito da cinza de casca de arroz e da sílica ativa”. Dissertação (Mestrado), Universidade Federal de Goiás, Escola de Engenharia Civil. 1999.

[7] ANDRADE, T., et al., "Investigação do potencial de reatividade para o desenvolvimento de RAA dos agregados miúdos e graúdos comercializados na Região Metropolitana do Recife". In: II Simpósio Sobre Reação Álcaliagregado em Estruturas de Concreto. 2006, Rio de Janeiro. Anais. São Paulo: IBRACON, 2006. 1 CD-ROM.

[8] METHA, P. K. e MONTEIRO, P. J. M. Concreto: Estrutura, Propriedades e Materiais. São Paulo: PINI. 2014.

[9] BALBO, F. A. N. "Um modelo matemático para a formação, difusão e dano químico causado pelo gel formado na reação álcali-sílica no concreto de cimento Portland". Tese de doutorado. Universidade Federal do Paraná. Curitiba, 2015.

[10] NEVILLE, A. M. Propriedade dos Concreto. $5^{\text {a }}$ Edição. São Paulo, 2016.

[11] RAJABIPOUR, F.; GIANNINI, E.; DUNANT, C.; IDEKER, J. H.; THOMAS, M. D. A. Alkali-silica reaction. Current understanding of the reaction mechanisms and the knowledge gaps. Cement and Concrete Research, v.7, p. 130-146, 2015.

[12] TAYLOR, H. F. W. Cement Chemistry. 2 ed. London: Thomas Telford, 1997.

[13] HASPARIK, N. P. Reação Alcali-Agregado no concreto. Concreto: Ciência e Tecnologia. Vol 2. São Paulo, Brazil: IBRACON; 2011:933-1001.

[14] DENT GLASSER, L. S. e KATAOKA, N. The Chemistry of Alkali-aggregate Reaction. Cement and Concrete Research. v. 11, n. 3, p. 1-9, 1981.

[15] ASSOCIAÇÃO BRASILEIRA DE NORMAS TÉCNICAS (ABNT). NBR 15577: Agregados - Reatividade Álcaliagregado. Rio de Janeiro, 2008.
[16] VALDUGA, L. "Reação álcali-agregado: Mapeamento de Agregados Reativos no estado de São Paulo". Dissertação (Mestrado em Engenharia Civil) - Faculdade de Engenharia Civil, Universidade Estadual de Campinas (UNICAMP), São Paulo, 2002.

[17] SILVEIRA, J. F. A. et al.,. "Investigação da reatividade álcaliagregado e a confiabilidade dos métodos acelerados". In: Congresso Brasileiro de Concreto, 44, 2002, Belo Horizonte, Brasil. Anais. São Paulo: IBRACON, 2002.

[18] POOLE, A. B. Introduction to alkali-aggregate reaction in concrete. In: SWAMY, R. N. (Ed.) The alkali sílica reaction in concrete. Glasgow: Blackie and Son, 1992.

[19] VALDUGA, L. "Influência das condições de ensaio da ASTM C 1260 na verificação da reação álcali-agregado". Tese (Doutorado em Engenharia Civil) - Escola de Engenharia, Universidade Federal do Rio Grande do Sul (UFRGS), Porto Alegre, 2007.

[20] SILVA, P. N. "Curso sobre reação Álcali-Agregado". Recife, 2007.

[21] PRISZKULNIK, S. Inspeção e Diagnostico de Estruturas de Concreto Afetadas pelas Reações Cimento-Agregado. Concreto Ensino, Pesquisa e Realizações. Geraldo C. Isaia (Editor). IBRACON. São Paulo - 2005.

[22] ANDRADE, T. W. "Curso Sobre Reação Álcali-Agregado". Recife, 2007.

[23] SILVA, C. S.; AGUIAR, R.; RAMOS, J. L. M.; MONTEIRO, E. B. Considerações sobre a reação álcalis agregado e o conhecimento do mercado imobiliário do Recife acerca do tema. Conferência Nacional de Patologia e Recuperação de Estruturas (CONPAR), 2017.

[24] FONSECA, J. M. M.; SILVA, D. L; SAMPAIO, R. G. M.; MONTEIRO, E. C. B. Ação deletéria no concreto em decorrência da reação álcali agregado. Revista CENAR Congresso Mineiro de Engenharias e Arquitetura, v.02, n.02, 2016.

[25] GOMES, E. A. O. "Recuperação Estrutural de Blocos de Fundação Afetados Pela Reação Álcali-Agregado - a Experiência do Recife". Recife, Dissertação de Mestrado, Universidade Católica de Pernambuco, 2008.

[26] HELENE, Paulo; PACHECO, Jéssika; CARVALHO, Mariana. Engineering field tests for alkali-aggregate reaction. Revista Structural Concrete - Journal of the fib. Vol. 18. April. Issue 2. p., 349-355, 2017.

[27] HELENE, Paulo; MONTEIRO, Eliana; ANDRADE, Tibério. RAA em estrutura de concreto armado de uma edificação residencial. Revista IBRACON Concreto \& Construções, Ano XLIV, No83, Jul-Set 2016, p. 89-94, 2016.

[28] J. L. C. ENGENHARIA DE PROJETOS LTDA. "Projeto Estrutural de Recuperação dos Apoios da Ponte Governador Paulo Guerra". Rio de Janeiro, 2005.

[29] ASSOCIAÇÃO BRASILEIRA DE CIMENTO PORTAND (ABCP). A evolução da cultura da prevenção da reação álcaliagregado no mercado nacional. Concreto e Construções, v. 83, p.39-43, 2016. 